\title{
Banking Union under Construction: The Impact of Foreign Ownership and Domestic Bank Internationalization on European Union Member States' Regulatory Preferences in Banking Supervision
}

Citation for published version (APA):

Spendzharova, A. (2014). Banking Union under Construction: The Impact of Foreign Ownership and Domestic Bank Internationalization on European Union Member States' Regulatory Preferences in Banking Supervision. Review of International Political Economy, 21(4), 949-979.

https://doi.org/10.1080/09692290.2013.828648

Document status and date:

Published: 01/01/2014

DOI:

$10.1080 / 09692290.2013 .828648$

Document Version:

Publisher's PDF, also known as Version of record

Document license:

Taverne

Please check the document version of this publication:

- A submitted manuscript is the version of the article upon submission and before peer-review. There can be important differences between the submitted version and the official published version of record. People interested in the research are advised to contact the author for the final version of the publication, or visit the DOI to the publisher's website.

- The final author version and the galley proof are versions of the publication after peer review.

- The final published version features the final layout of the paper including the volume, issue and page numbers.

Link to publication

\footnotetext{
General rights rights.

- You may freely distribute the URL identifying the publication in the public portal. please follow below link for the End User Agreement:

www.umlib.nl/taverne-license

Take down policy

If you believe that this document breaches copyright please contact us at:

repository@maastrichtuniversity.nl

providing details and we will investigate your claim.
}

Copyright and moral rights for the publications made accessible in the public portal are retained by the authors and/or other copyright owners and it is a condition of accessing publications that users recognise and abide by the legal requirements associated with these

- Users may download and print one copy of any publication from the public portal for the purpose of private study or research.

- You may not further distribute the material or use it for any profit-making activity or commercial gain

If the publication is distributed under the terms of Article $25 \mathrm{fa}$ of the Dutch Copyright Act, indicated by the "Taverne" license above,

Download date: 26 Apr. 2023 


\section{Banking union under construction: The impact of foreign ownership and domestic bank internationalization on European Union member- states' regulatory preferences in banking supervision}

\section{Aneta B. Spendzharova}

To cite this article: Aneta B. Spendzharova (2014) Banking union under construction: The impact of foreign ownership and domestic bank internationalization on European Union member-states' regulatory preferences in banking supervision, Review of International Political Economy, 21:4, 949-979, DOI: $10.1080 / 09692290.2013 .828648$

To link to this article: https://doi.org/10.1080/09692290.2013.828648

Published online: 29 Oct 2013.

Submit your article to this journal $₫$

山ll Article views: 1119

Q View related articles ¿

View Crossmark data ¿

Citing articles: 17 View citing articles $[7$ 


\title{
Banking union under construction: The impact of foreign ownership and domestic bank internationalization on European Union member-states' regulatory preferences in banking supervision
}

\author{
Aneta B. Spendzharova \\ Department of Political Science, Maastricht University, Maastricht, \\ The Netherlands
}

\begin{abstract}
What is the optimal scope of regulatory harmonization in European financial sector governance? I argue that the levels of foreign ownership and domestic bank internationalization are important determinants of the extent to which governments are prepared to endorse European solutions in banking supervision or prefer national ones. I test two hypotheses about the impact of foreign ownership and domestic bank internationalization on regulatory preferences. This article shows that being a host jurisdiction to foreign financial institutions constrains states' ability to steer credit flows and tackle perceived threats to national financial stability. As a consequence, decision-makers seek to preserve some national regulatory autonomy. Especially during economic downturns, national supervisory authorities have strong incentives to pursue policies that minimize losses for domestic stakeholders and shift burdens onto foreign ones.
\end{abstract}

\section{KEYWORDS}

EU banking union; EU financial regulation; de Larosière reforms; Capital Requirements Directive; CRD IV; EU banking supervision.

European policymakers have been negotiating measures to complete the single market in financial services since the late 1990s. While single market initiatives produced visible results in sectors such as trade, research and development, and transport, financial services lagged behind (see Howarth and Sadeh, 2010; Quaglia, 2010). Discussions about transferring 
more decision-making, monitoring and sanctioning competences to the EU level gained renewed salience in the aftermath of the 2008 global financial crisis. Bedevilled by a sovereign debt crisis in member-states such as Greece, Ireland and Portugal, the European Union (EU) has been inching toward establishing a banking union to reinforce its system of economic governance (Buckley, Howarth and Quaglia, 2012; Buiter and Rahbari, 2012; Dinan, 2012; Hodson, 2012). Yet, the process has been slow and fraught with disagreements about the optimal scope of regulatory coordination (Barker, 2012; Buckley, Howarth and Quaglia, 2012; Jenkins, 2012).

Some member-states, such as France, have consistently advocated centralized European financial regulation, which would create more systematic oversight of financial conglomerates operating in Europe (Buckley and Howarth, 2010; Grossman and Leblond, 2011). The European Commission, financial industry groups and, especially, large cross-border financial institutions have also supported more centralization, anticipating gains from economies of scale in a more coherent European banking union. Posner and Véron (2010) have shown that, in the early 2000s, the European Commission was particularly adamant about achieving optimal financial markets integration. Moreover, Quaglia (2007) has found that the biggest supporters of a harmonized European approach were transnational interest groups and firms with substantial activities in more than one EU state, rather than purely domestic actors.

However, many policy proposals for further harmonization have been met, at best, with hesitation by other EU member-states. Czech decisionmakers, for example, have voiced concerns that ceding more sovereignty to the European level would tie the hands of national financial supervisors and undermine their ability to respond to risks in the national market in a timely and efficient manner (Spendzharova, 2012). From a broader perspective, a real estate bubble in the Czech Republic may look like an isolated threat to the EU's financial stability, but national supervisors want to keep the powers to impose stricter capital requirements if they are concerned about domestic financial stability. Why do we observe such conflicting preferences among EU member-states about the scope of further harmonization in financial sector governance?

I argue that the structure of the domestic financial sector, in particular the levels of foreign ownership and domestic bank internationalization, are important determinants of the extent to which governments are prepared to endorse EU-level solutions in banking regulation. Levels of foreign ownership and domestic bank internationalization vary significantly across the EU. In the decades after the Single European Act, the EU has launched a number of harmonization initiatives to expand and consolidate the internal market (Armstrong and Bulmer, 1998; Howarth and Sadeh, 2010). These measures, coupled with the liberalization of the global financial markets 
and competitive pressures, have provided a boost for cross-border banking in Europe and financial conglomerates (Deutsche Bank Research, 2008; European Commission, 2009b). While foreign ownership in the banking sector has increased substantially in the EU's 'new' member-states from Central and Eastern Europe (CEE) since the mid-1990s, other states such as Sweden, France, Germany, Italy and Spain have kept traditionally low levels of foreign ownership in their banking sectors and have championed highly internationalized domestic banks. Luxembourg and the UK are among the few 'old' EU member-states with relatively high levels of foreign ownership (European Commission, 2009b).

The latest reform packages in EU financial sector governance such as de Larosière and the Capital Requirements Directive (CRD) IV provide us with systematic evidence about the diverging preferences of EU memberstates. The dependent variable in my analysis is government preferences about banking supervision reforms. The main independent variables are foreign ownership and domestic bank internationalization, but I also consider government Euro-scepticism and ideational factors as alternative explanatory variables. I argue that states with low levels of foreign ownership and highly internationalized domestic banks favour maximum regulatory harmonization in banking supervision to maintain a level playing field. In contrast, states with very high levels of foreign ownership and low domestic bank internationalization demand safeguards to preserve some national regulatory autonomy.

Regulatory dilemmas about the optimal scope of policy coordination in Europe are a microcosm of financial policy coordination at the international level. Uneven levels of foreign ownership in an integrated economic space create challenges for effective policy coordination between states (see Epstein, 2013a: Introduction to this volume). Over the past two decades, West European states have nurtured national champions in banking, despite uncertainty over whether these privately-owned financial conglomerates would bring benefits to the home jurisdiction. This article shows that being a host jurisdiction to foreign financial institutions limits states' ability to steer credit flows. This, in turn, raises decisionmakers' sensitivity toward a full-scale transfer of regulatory authority away from the national level. They seek to preserve regulatory tools that would enable them to intervene when they deem it necessary. During crises, bank bail-out schemes tend to be nationally-oriented (Centre for Economic Policy Research, 2011; Epstein, 2013b, this volume). Domestic regulatory authorities have strong incentives to pursue unilateral policies that minimize losses for domestic stakeholders and shift burdens onto foreign ones (Kudrna and Gabor, 2013). The extent to which EU memberstates manage to reconcile their diverging preferences and cooperate effectively has important repercussions for European and global financial stability. 
This article is organized as follows: Section 1 outlines in greater detail the recent de Larosière and CRD IV regulatory reforms in the EU. The analysis focuses on three policy issues in banking sector supervision selected from the larger legislative packages. These three issues represent areas in which substantial progress has been made toward greater harmonization at the EU level, yet member-states clearly disagreed about the scope of desirable regulatory harmonization. Section 2 presents the analytical framework. Section 3 is dedicated to empirical analysis, using data from official positions filed by EU member-states and private actors in a series of public stakeholder consultations. Section 4 outlines two alternative accounts of the observed outcome. Section 5 summarizes the main findings.

\section{SECTION 1}

\section{BANKING SUPERVISION REFORMS IN THE EU: THE DE LAROSIÈRE PACKAGE AND CRD IV}

I investigate how foreign ownership and domestic bank internationalization have influenced EU member-states' regulatory preferences in three substantively important areas of banking supervision after the 2008 global financial crisis. Initiatives to integrate the European financial markets and supervision date back to the late 1990s. Posner and Véron (2010) have shown that the European Commission played a central role in initiating the de Larosière report and, subsequently, developing a blueprint for more centralized European supervisory authorities. They observed significant intergovernmental and inter-institutional constraints on how far centralization could go (Posner and Véron, 2010). The European Commission and Parliament have consistently pursued greater regulatory convergence in the EU (The Financial Times, 2009; EurActive, 2010; Tait, 2010). However, these legislative initiatives were met with resistance by some memberstates, which preferred more national regulatory autonomy in finance, such as the UK and the Czech Republic (Buckley and Howarth, 2010; Grossman and Leblond, 2011; Spendzharova, 2012).

Thus, policy coordination in European financial sector governance has proceeded slowly, following protracted negotiations. In 1999, the European Commission launched the Financial Services Action Plan (FSAP) to reinvigorate financial sector harmonization and boost the gains from economies of scale and greater competition in the internal market. Due to its slow implementation, in 2000, the Economic and Financial Affairs Council (ECOFIN) Council of Ministers appointed an expert committee, chaired by Alexandre Lamfalussy, to speed up EU-wide convergence in regulating securities markets. The committee developed a four-level regulatory approach, often referred to as the Lamfalussy framework, which was extended to banking and insurance (Quaglia, 2007; Posner, 2010). 
After the FSAP, the Commission's White Paper on Financial Services 2005-10 provided a vision for developing the single market in financial services (European Commission, 2005). There were some advances toward greater regulatory coherence in the EU, but important problems persisted. For example, Grossman and Leblond (2011: 425) have concluded that while wholesale markets for financial services were fairly well integrated across the EU, ownership structures and processes of consolidation remained predominantly national. The onset of the global financial crisis in 2008 provided the impetus for major reforms in European financial regulation such as the so-called de Larosière package and an extensive revision of the EU's CRD to implement the Basel III accords. The on-going redesign of European financial regulation also has important implications for transatlantic regulatory cooperation and international financial regulation (Porter, 2003; Moschella, 2010; Lütz, 2011).

Next, I discuss three policy issues in which substantial progress has been made toward greater harmonization at the EU level. The first issue refers to granting more binding regulatory powers to the supranational European Supervisory Authorities (ESAs). Some EU member-states were in favour of transferring considerable binding powers to the ESAs in pursuit of a level playing field and greater regulatory coherence across the EU, while others preferred to keep more national regulatory autonomy. The second issue is distributing supervisory power and competences between the home and host supervisory organizations of cross-border financial institutions. The third issue concerns introducing a single rule-book in banking and discontinuing national discretions in the CRD IV.

\section{European Supervisory Authorities (ESAs)}

The transfer of regulatory powers from the national level to EU regulatory agencies rarely proceeds smoothly and without objections from important participants in the European policy process (Groenleer, 2011). Creating three European authorities to oversee banking, securities and insurance was not an exception. Level 3 committees (Committee of European Banking Supervisors (CEBS), Committee of European Securities Regulators (CESR), Committee of European Insurance and Occupational Pensions Supervisors (CEIOPS)), the most innovative institutional feature of the Lamfalussy regulatory framework, were the institutional predecessors to the three ESAs. They were set up to foster the exchange of best practices across member-states and sectors, and to facilitate regulatory convergence (European Central Bank, 2007). However, they could only issue non-binding recommendations. The three committees took proactive steps to ensure greater regulatory coherence by implementing a joint cooperation protocol. They made significant advances in sharing information, exchanging experiences and reducing reporting duplication 
(European Central Bank, 2007). Yet, under the non-binding legal regime, if a member-state disagreed with the recommendations of the Level 3 committees, it could still pursue its own national policies.

In the aftermath of the 2008 global financial crisis, the European Commission launched a new initiative to redesign the European financial architecture following the recommendations of another high-level expert group, chaired by Jacques de Larosière (see Donnelly, 2010; Quaglia, 2010; Buckley and Howarth, 2011). The reforms created a European Systemic Risk Board (ESRB) in charge of macro-prudential supervision - monitoring and assessing systemic risk in European financial markets. A second institution - the European System of Financial Supervisors (ESFS) - complements the ESRB in the area of micro-prudential supervision.

The ESFS includes the three new ESAs in banking, securities and insurance (European Commission, 2009c). It caused considerable controversy during the EU inter-institutional negotiations. In contrast to the earlier framework, the de Larosière reform package empowered the ESAs to issue decisions with binding power (Donnelly, 2010). Fully operational since January 2011, they have been developing common supervision rule-books in their respective sectors. The new legal regime empowers the ESAs to make decisions with a direct and binding effect on market participants and national supervisory organizations. Member-states in favour of greater centralization and harmonization of financial regulation as well as the European Commission and Parliament welcomed the enhancement of the ESAs' powers. In contrast, other member-states voiced concerns about possible fiscal burdens and loss of sovereignty when decisions with important national repercussions are taken at the European level (Spendzharova, 2012).

\section{Home-host supervision}

Another substantively important policy issue where EU member-states' preferences have diverged refers to division of powers and competences between the home and host regulators of cross-border financial institutions. Since the late 1980s, supervisory colleges were formed to oversee the activities of banks with large cross-border operations. The colleges brought together supervisors from diverse jurisdictions such as the Cayman Islands, France, Germany, Hong Kong, Luxembourg, Spain, Switzerland, the United Arab Emirates, the UK and the USA. The colleges met on a regular basis to discuss the supervision of a particular financial institution, identify issues or problems early on and take actions to reduce the risk of a bail-out or bank failure. However, in the early colleges, no single supervisor took the lead and problems fell through the regulatory cracks. As Alford (2010: 58) notes, the Group of 20 (G-20) and the EU have been very active in developing the operational framework of supervisory colleges and codifying best practices to improve their effectiveness. 
Level 3 Lamfalussy committees, CEBS, CESR and CEIOPS, were given extensive tasks to facilitate the sharing of prudential information within cross-border financial institutions operating in the EU (Alford, 2010: 61). During 2006-07, the three Lamfalussy committees fostered the signing of memoranda of understanding between home and host supervisors. These measures were intended to create a clear division of labour between the home supervisor in the state where the financial conglomerate was officially registered and host supervisors in states where the financial institution had branches and subsidiaries.

Even before the global financial crisis of 2008, there were recurrent disagreements among member-states about the appropriate division of tasks between home and host supervisors during the preparation of legislation in all three financial sectors - banking, securities and insurance. The issue was discussed extensively in 1999 in the context of negotiating the CRD. The tensions were even more noticeable during the preparation of the Solvency II Directive when the new EU member-states from CEE fully participated in the negotiations (Personal Interview 2, 2011). As Kudrna and Gabor (2013) have argued, financial crises create short-term incentives for non-cooperative behaviour in supervisory colleges because home and host countries try to minimize their own losses. Furthermore, the primary role of supervisory colleges is to safeguard the financial stability of the financial group as a whole, which may entail shutting down uncompetitive smaller operations in individual countries. This is a sensitive issue for smaller EU member-states with predominantly foreign-owned financial sectors. They are concerned that they will be unable to prevent dramatic capital outflows.

Dividing tasks and responsibilities between home and host supervisors re-emerged as a divisive issue during the negotiations of the de Larosière reforms. For host countries, a regulatory framework which gives more powers to the ESAs than to home supervisors is preferable to the status quo. At the same time, host supervisors wish to preserve some national regulatory autonomy, especially concerning fiscal burden-sharing (National Bank of Poland, 2010). As Kudrna (2012) has shown, the EU tried to respond to this challenge before the 2008 global financial crisis by developing a regime that relied mostly on soft-law agreements. That regime failed to produce the desired results, as shown by the protracted bankruptcy of European cross-border banks such as Fortis (Centre for Economic Policy Research, 2011). At present, there is a renewed effort to create a common European bank resolution regime, but the legislation is highly contested (Barker, Peel and Wiesmann, 2013).

\section{National discretions and the single rule-book in the CRD}

The third policy issue examined in this article concerns the single rule-book in banking and the proposed discontinuation of national discretions in the 
CRD IV. The most recent revision of CRD implements the Basel III accords in the EU and covers a wide range of issues. It seeks to induce more robust capital adequacy levels across the EU, but also to mitigate pro-cyclicality, strengthen liquidity risk requirements and set aside provisions for credit losses (European Commission, 2011a). Examining the entire content of CRD IV, Howarth and Quaglia (2012) have argued that EU member-states' positions are driven by national concerns about bank competitiveness and impact on the broader economy. In this article, I focus on one aspect of CRD IV that is very important for banking supervision - the single rule-book.

Discussions about the single rule-book reflect underlying preferences about minimum versus maximum regulatory harmonization in the EU. A minimum harmonization approach allows member-states to impose stricter prudential rules on banks operating in their jurisdiction, driven by concerns about national financial stability. The advantage of minimum harmonization is that it gives discretionary powers to national supervisory authorities to deviate from CRD provisions. At the same time, the minimum regulatory harmonization approach has come under attack because it creates opportunities for 'gold-plating'. It allows risk-averse national regulators to set higher capital requirements for the entire banking sector in their jurisdiction, regardless of individual banks' risk management strategies.

In contrast, a maximum harmonization approach curtails the discretions available to national banking supervisors. This approach aims to create legal clarity and coherence, ensure a level playing field and foster supervisory convergence across member-states. The newly set-up European Banking Authority (EBA) plays a central role in monitoring the adopted set of harmonized rules. However, critics point out that some markets in the EU such as foreign currency lending and real estate mortgage finance are still segmented and show divergent dynamics at the national level. Taking away the discretions of national supervisors to impose stricter rules in response to local imbalances could, in the end, be detrimental for national financial stability (European Commission, 2011b).

The single rule-book once again reveals different views about the optimal scope of policy coordination in the EU. On the one hand, the generally pro-integration EU institutions, such as the European Commission and Parliament, as well as member-states, such as France, have advocated a maximum harmonization approach. On the other hand, member-states that attach more importance to national regulatory autonomy, such as the UK and the Czech Republic, have emphasized the merits of minimum regulatory harmonization. Moreover, discussions about the single rule-book echo existing debates about home-host supervision. Home countries tend to prefer maximum harmonization; host countries tend to be the most vehement proponents of preserving national discretions and minimum regulatory harmonization across the EU. We now turn to the theoretical underpinning of my analysis. 


\section{SECTION 2}

\section{MEMBER-STATE PREFERENCES ABOUT EUROPEAN BANKING SUPERVISION}

Negotiations among the EU institutions and member-states in the EU legislative process are more structured and institutionalized than negotiations of international agreements. EU member-states have already pooled significant aspects of their sovereignty and transferred decision-making competences to supranational institutions such as the European Commission and Parliament. At the same time, whenever a new policy issue emerges and decisions need to be made about further transfers of decision-making power from the national to the European level, member-state governments face dilemmas very similar to those observed in international negotiations. The rich literature on multi-level governance in the EU has established that national governments are not the only key players in EU policymaking. In many issue areas, sub-national regions and private actors, for example, can bypass national governments and influence the EU institutions directly (Hooghe and Marks, 2003; Bache and Flinders, 2004; Piattoni, 2010). These insights are important when we consider the input of pan-European financial sector associations in the European Commission's stakeholder consultation process. At the same time, a comprehensive analysis of the multi-level EU policymaking process in financial regulation is beyond the scope of this article.

My main goal here is to unpack the effect of foreign ownership and domestic bank internationalization on governments' regulatory preferences in banking supervision. My analysis is embedded in the political economy literature on the distributional effects of international rule harmonization (Garrett, 1992; Oatley and Nabors, 1998; Singer, 2004, 2007). I am particularly interested in the consequences of European regulatory harmonization for national regulatory autonomy. As in other policy areas, we observe a trade-off: the more decision-making powers are transferred to the European level, the less discretion remains at the national level. Under what conditions are member-state governments willing to give up national regulatory autonomy in order to achieve greater European regulatory harmonization?

I draw on the literature that has analysed the impact of domestic politics on regulatory preferences (Hosli, 2000; Frieden, 2002; Rosenbluth and Schaap, 2003; Singer, 2007; Buckley and Howarth, 2010; Lütz, 2011). As Singer (2007) has argued, maintaining the competitiveness of the domestic banking sector is a primary concern for regulators in international negotiations, especially in the face of instability and exogenous shocks. Stricter regulation in host jurisdictions can undermine the competitiveness of banks with a highly internationalized profile. In this context, pursuing international regulatory harmonization can help maintain a level playing field and 
safeguard the competitiveness of a highly internationalized banking sector. Similarly, regarding EU financial regulation reforms, Quaglia (2008b: 53) has shown that 'the most competitive and outwards-oriented part of the banking industry in both Germany and the UK endorsed the Lamfalussy framework in such a way as to promote further market integration'.

Two variables play a central role in my analysis - the extent of foreign ownership in the banking sector and the degree of internationalization of domestic banks. Figures 1 and 2 summarize where EU member-states are situated along these two dimensions. My argument yields clear expectations about the top right and bottom left corners of Figure 1. I expect that countries where domestic bank internationalization is high and foreign ownership is low would favour EU-wide regulatory harmonization. In contrast, I expect that countries where foreign ownership is high and domestic bank internationalization is low would prefer to preserve some national regulatory autonomy. Below, I present two hypotheses about EU member-states' preferences in banking supervision.

Hypothesis I: States where foreign ownership in banking is low and domestic banks are highly internationalized prefer greater European regulatory harmonization in banking supervision.

\section{Greater regulatory harmonization in banking supervision}

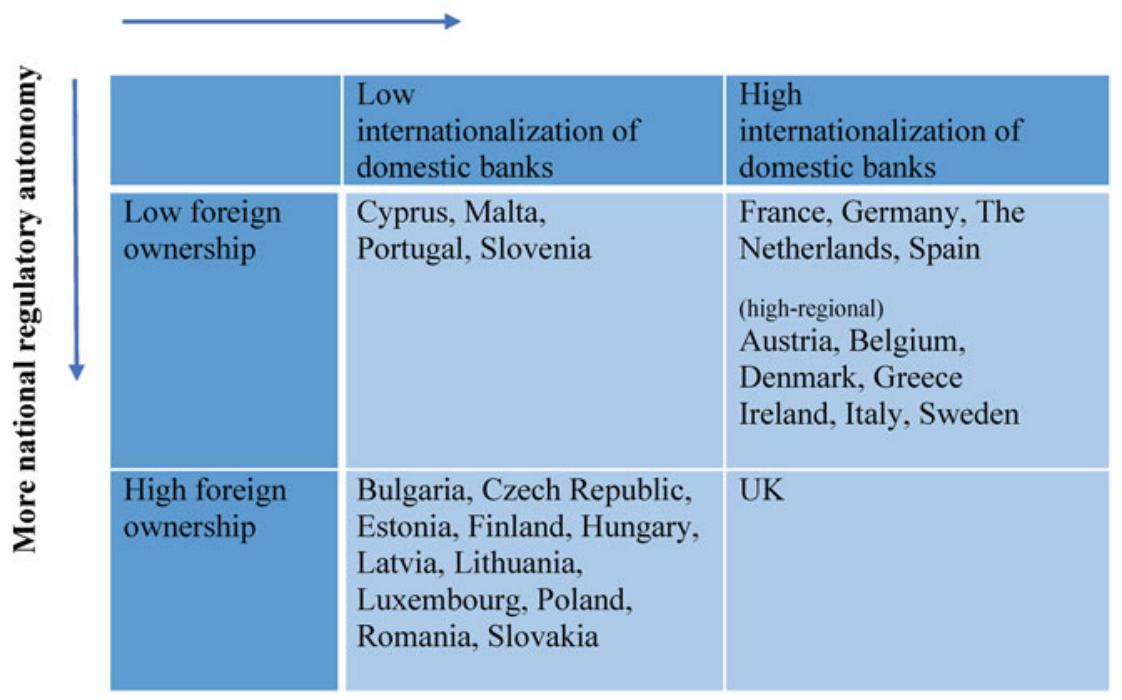

Figure 1 The interplay of foreign ownership and domestic bank internationalization. 


\begin{tabular}{lcccc}
\hline $\begin{array}{l}\text { European } \\
\text { Union } \\
\text { member-state }\end{array}$ & $\begin{array}{c}\text { Level of } \\
\text { foreign } \\
\text { ownership } \\
\text { in banking, } \\
\mathbf{2 0 0 8}\end{array}$ & $\begin{array}{c}\text { Internationali- } \\
\text { zation of } \\
\text { domestic banks, }\end{array}$ & $\begin{array}{c}\text { Euro- } \\
\text { scepticism } \\
\text { government } \\
\text { score }\end{array}$ & $\begin{array}{c}\text { Position on } \\
\text { EU } \\
\text { banking } \\
\text { supervision } \\
\text { reforms }\end{array}$ \\
\hline Austria & 19.5 & high-regional & 5.9 & 3 \\
Belgium & 24.9 & high-regional & 6.6 & 3 \\
\hline Bulgaria & 83.9 & low & 6.7 & 2 \\
\hline Cyprus & 30.3 & low & n/a & 3 \\
\hline Czech Republic & 96.9 & low & 3.0 & 1 \\
\hline Denmark & 20.1 & high-regional & 6.0 & 3 \\
\hline Estonia & 98.5 & low & 6.6 & 3 \\
\hline Finland & 56.5 & low & 6.1 & 2 \\
\hline France & 11.0 & high & 6.0 & 5 \\
\hline Germany & 11.1 & high & 5.6 & 3 \\
\hline Greece & 37.4 & high-regional & 6.1 & 3 \\
\hline Hungary & 56.3 & low & 6.6 & 3 \\
\hline Ireland & 43.2 & high-regional & 5.7 & 3 \\
\hline Italy & 13.9 & high-regional & 4.7 & 5 \\
\hline Latvia & 64.8 & low & 5.2 & 3 \\
\hline Lithuania & 76.7 & low & 6.2 & 2 \\
\hline Luxembourg & 94.6 & low & n/a & 2 \\
\hline Malta & 37.3 & low & n/a & 3 \\
\hline The Netherlands & 14.8 & high & 4.6 & 4 \\
\hline Poland & 65.4 & low & 6.6 & 3 \\
\hline Portugal & 22.3 & low & 7.0 & 5 \\
\hline Romania & 87.7 & low & 6.3 & 3 \\
\hline Slovakia & 92.3 & low & 5.0 & 2 \\
\hline Slovenia & 28.9 & low & 6.5 & 2 \\
\hline Spain & 11.4 & high & 6.0 & 3 \\
\hline Sweden & 8.9 & high-regional & 6.3 & 4 \\
\hline United Kingdom & 50.3 & high & 2.3 & 1 \\
\hline
\end{tabular}

Figure 2 Foreign ownership, bank internationalization and EU member-states' positions on banking supervision reforms. Sources: Foreign ownership: Deutsche Bank Research (2008); Bank internationalization: Slager (2005); Claessens et al. (2010); CEPR (2011); Euro-scepticism: Author's calculation based on Chapel Hill Expert Survey (Bakker et al., 2012); Positions: Author's questionnaire.

The causal mechanism at work in this hypothesis is that greater regulatory harmonization at the EU level would create a level playing field and reduce the costs of legal compliance in different jurisdictions. We would expect large financial firms in these countries to prefer greater oversight powers for their home regulators in the supervisory colleges of crossborder financial institutions. We would also expect that large financial firms will actively seek to shape the home government's position in accordance with their business interests. 
Hypothesis II: States where foreign ownership in banking is high and domestic bank internationalization is low prefer more national regulatory autonomy.

The causal mechanism here is that banking supervisors in host countries are wary of giving up regulatory tools that allow them to steer credit flows in a direction that is most compatible with their national mandate and policy priorities. The vulnerability of host jurisdictions vis-à-vis subsidiaries and branches of foreign financial institutions makes them adamant to preserve more national regulatory autonomy. Section 3 probes the empirical validity of these two hypotheses.

The UK is an idiosyncratic case, the only one occupying the bottom right corner of Figure 1 of countries with highly internationalized domestic banks that also host foreign financial institutions. The UK government experiences conflicting pressures from domestic stakeholders. The internationalized domestic banks push for an advantageous regulatory climate in Europe. However, UK bank supervisors also have to deal with some of the vulnerabilities of states with high levels of foreign ownership. I discuss the UK case in greater detail at the end of Section 3. In the same sub-section, I elaborate on the position of countries such as Slovenia and Portugal situated in the top left corner of Figure 1.

\section{SECTION 3}

\section{THE IMPACT OF FOREIGN OWNERSHIP AND DOMESTIC BANK INTERNATIONALIZATION ON EU MEMBER-STATES' REGULATORY PREFERENCES IN BANKING SUPERVISION}

Figure 2 summarizes the level of foreign bank ownership in all EU memberstates at the time of the de Larosière reforms, 2008-10, measured as the percentage of total assets in the banking system owned by foreign financial institutions (Deutsche Bank Research, 2008). The reported level of domestic bank internationalization is based on Slager (2005), Claessens et al. (2010) and a study by the Centre for Economic Policy Research (Centre for Economic Policy Research, 2011). The most internationalized banking systems such as those in France, Germany, the UK and the Netherlands have a clear global presence and are coded as 'high' on the internationalization variable. I use the category 'high-regional' for EU member-states where bank internationalization has a more limited regional focus. For example, Swedish and Danish banks have pursued internationalization in Northern Europe and the Baltic region (European Commission, 2009b). Austrian banks have internationalized in CEE, and Greek banks had focused on the Balkans before the Eurozone sovereign debt crisis (Centre for Economic Policy Research, 2011). 
Figure 2 also reports an index of whether a state's preferences were favourable to transferring power to the EU level or preserving national regulatory autonomy, based on a questionnaire circulated among officials who participated in the negotiations of the regulatory framework. As the response rate was not high $(n=9)$, the scores are broadly indicative, but not exact estimates of countries' positions, for which a larger number of responses would be necessary. The ordinal scale runs from 1 to 5 , where higher values indicate willingness to transfer more powers to the EU level and lower values indicate preference to keep more regulatory powers at the national level. Lastly, the figure presents estimates of the level of government Euro-scepticism, which is an important alternative explanation of the observed regulatory positions discussed later in the article. The government Euro-scepticism scores are based on the 2010 Chapel Hill expert survey (Bakker et al., 2012). Low values mean opposition to European integration, whereas high values mean support for European integration; the range is 1 to 7 .

To outline the general logic of my argument, we would anticipate that countries with the lowest levels of foreign ownership and most internationalized domestic banks, such as France, Germany, Italy, the Netherlands and Sweden, will be the staunchest proponents of financial regulation centralization at the EU level and more binding decision-making powers for the ESAs. We would also expect countries with low levels of foreign ownership to advocate greater regulatory powers of home supervisory institutions vis-à-vis host ones and prefer maximum regulatory harmonization in the EU. In contrast, we would expect countries where foreign ownership is very high and domestic bank internationalization is very low, such as the EU's new member-states from CEE and Finland, to advocate greater discretionary powers for their national, also referred to as host, banking sector regulators.

Is there sufficient empirical evidence in support of these hypotheses? Below, I examine the official positions filed by public and private actors in a series of public stakeholder consultations launched by the European Commission. The sub-section dedicated to each hypothesis starts with an analysis of a typical case: France for the low foreign ownership and high domestic bank internationalization group and the Czech Republic for the high foreign ownership and low domestic bank internationalization group. To check the broader validity of my argument, I subsequently consider the official positions of more countries from each group.

Hypothesis I: States where foreign ownership in banking is low and domestic banks are highly internationalized prefer greater European regulatory harmonization in banking supervision.

I first analyse the French position on the powers of the ESAs, home-host supervision issues and the single rule-book in CRD IV. France is a typical 
case of the low foreign ownership and high domestic bank internationalization group in my analysis. The official positions of the French public authorities do, indeed, demonstrate support for greater centralization of financial regulation at the European level and empowering the ESAs. The French Financial Markets Authority (AMF), for example, states that 'the AMF has for several years pleaded for an effective harmonization of implementing measures in the European single market, based on enhanced powers of CESR' (French Financial Markets Authority, 2009: 1). The AMF supports greater decision-making powers for the ESAs, in particular in the securities sector, and advocates greater institutional independence for these (French Financial Markets Authority, 2009: 2). Concerned about possible interference from the member-states, Commission or Parliament, the AMF would like to see greater legal safeguards for the ESAs' arbitration powers. Furthermore, the position emphasizes the important role that home regulators play in the oversight of cross-border conglomerates. In this regard, the ESAs can improve the functioning of home-host supervisory cooperation by creating a framework for delegating tasks and organizing joint investigations and inspections (French Financial Markets Authority, 2009: 3).

The joint official position of the French Treasury, Bank of France and Bank Supervision Authority (Autorité de Contrôle Prudentiel) on CRD IV shows a clear preference for maximum regulatory harmonization in the European financial sector. It states that 'France supports a reduction in the number of national options and discretions within the CRD' (France, 2010: 27). The French public authorities stress the importance of equal treatment of all banks across the EU and point out that 'France has not identified areas where national or market specific circumstances necessitate a more stringent general requirements or stricter rules' (France, 2010: 27). The position dismisses concerns about the specificities of local markets and argues that existing regulatory tools can be used to prevent real estate bubbles without imposing national discretion measures, such as higher capital adequacy levels and provisions against losses (France, 2010: 29).

The position of French public authorities is congruent with those of large private financial institutions based in France, which supports the assumption that important domestic stakeholders have an impact on the government's regulatory stance. For example, cross-border bank Crédit Agricole welcomes the extension of the ESAs' binding decision-making competences and stresses its preference for 'a binding mediation mechanism led by the ESAs' (Crédit Agricole, 2009: 2). According to Crédit Agricole (2009), centralizing financial regulation at the European level would ensure consistent application of EU rules and contribute to a level playing field in the European single market in financial services.

With respect to home-host supervision issues, another France-based financial conglomerate, BNP Paribas, emphasizes that the colleges of 
supervisors should be the lynchpin of the supervisory system and should play an important role in ensuring a balanced flow of information between home and host supervisors' (BNP Paribas, 2009: 2). The bank clearly prefers a more prominent role for home supervisors: 'In case consensus cannot be fully reached [in the supervisory college of a cross-border group], the home supervisor ends the debate by making the appropriate decision, taking into account the different views and concerns exposed' (BNP Paribas, 2009: 4). Crédit Agricole echoes this stance: 'The consolidating [home] supervisor would have the legal authority to make decisions about the most important prudential aspects of the whole group' (Crédit Agricole, 2009: 2). BNP Paribas supports the development of a single European rule-book in supervision to promote efficiency of scale and maintains that 'national options must be eradicated' (BNP Paribas, 2009: 1).

So far, we have observed that the positions of French public actors on EU financial regulation are largely congruent with those of large financial institutions based in France. This resonates with Buckley and Howarth's (2010: 125) finding that 'French government support for the de Larosière proposals reflected the broadly supportive position of national financial interest groups'. We know from previous research that other EU states with large financial sectors such as Germany and the Netherlands were under pressure from the financial industry to pursue a common European rulebook and greater supervisory convergence across the EU (Mügge, 2010). This would allow financial conglomerates to maximize their gains from economies of scale.

The remainder of this section examines evidence about the regulatory preferences of other countries in the low foreign ownership and high domestic bank internationalization group. The official German position on EU financial regulation reforms is not publically available, but we have access to the positions of important private stakeholders such as the Association of German Banks (BV). In line with Hypothesis I, the BV welcomes the revamping of the ESAs because 'concentration of competences at a central European body is essential for the effective supervision of institutions' (Association of German Banks, 2009: 4). It endorses the efforts to harmonize supervisory law, powers and sanctions in order to exercise more effective oversight over cross-border groups. The BV also welcomes the measures to strengthen the system of supervisory colleges in the new European financial regulation architecture, but stresses that any binding mediation procedures should be 'subordinate and auxiliary to the final say of the consolidated [home] supervisor' (Association of German Banks, 2009: 6).

The Italian Central Bank is in favour of uniform financial regulation standards in the EU. The Central Bank urges the EBA to get closely involved in the development of binding technical standards. Furthermore, it stresses the importance of effective collaboration between home and host supervisors, for example, by enhancing information sharing. According 
to the Italian Central Bank, supervisory colleges are at the centre of the new European system of financial supervision. They should be seen as the appropriate coordination structure for reaching joint assessments and decisions to follow up on the technical standards drawn up by the EBA (Bank of Italy, 2010: 1-2). This position is more in line with the interests of home countries and supports Hypothesis I.

Cross-border financial conglomerate UniCredit, which is partly based in Italy, agrees that the ESAs should play a greater role in mediating conflicts between national supervisors, but insists that the parent group has the obligation to manage its constituent parts most effectively (UniCredit, 2009b: 1-2). A report by the group's regulatory policy unit acknowledges the existence of home-host supervisor tensions in terms of capital allocation: 'The geographic mobility of resources may, in some instances, make some host markets thin in terms of capital assets and liquidity' (UniCredit, 2009a: 11). The report asserts that multinational banks can be trusted as they have contributed to economic growth in CEE. They have helped SMEs and private customers get access to credit that would otherwise have been unavailable or more expensive (UniCredit, 2009a: 11).

UniCredit stresses that multinational banks are complex organizations managed and coordinated by a parent company. In order to operate optimally as single entities, 'they must be free [internally] to channel funds towards the best use of resources' (UniCredit, 2010: 9). That is why the bank objects to measures strengthening the ability of national regulators to impose more stringent liquidity standards, not only at the group level, but also at the level of individual branches and subsidiaries. It views extensive national discretions as a threat to the single market because they can lead to asymmetric treatment of intra-group transactions (UniCredit, 2010: 9).

Several highly internationalized banks such as ING are based in the Netherlands and have been consistently advocating greater regulatory harmonization in the EU. At the same time, the country is also hosting foreign financial institutions and the government's official position is more balanced than those of private financial institutions. The Dutch official position on the financial regulation reforms is based on inputs from all key public actors such as the Dutch Central Bank (DNB), the Financial Markets Authority (AFM) and the Dutch Ministry of Finance. It explicitly states that the government has taken into account the inputs of important private actors such as the Netherlands Bankers' Association, Insurers' Association (Verbond van Verzekeraars), ABN AMRO, NYSE Euronext Amsterdam, Fortis, ING, Rabobank and SNS Real. Overall, the position tries to balance the different concerns of public and private actors. It supports the greater binding mediation powers of the ESAs, but also asks for clear guidelines about the limits of the ESAs' powers and strong accountability mechanisms (The Netherlands, 2009: 3-4). 
The individual positions of Dutch financial actors such as ING are much bolder than the official government position in demanding greater centralization of European financial regulation. According to ING (ING Group, 2009: 3), 'there is a need for more binding mechanisms and policy setting at the EU level' in order to pursue efficiency and coherence in the supervisory network of large financial institutions. ING is also in favour of more far-reaching binding mediation powers for the ESAs that go beyond dayto-day supervisory activities and extend to crisis management situations. The bank advocates 'a strong lead role for the home supervisor in determining the composition and agenda of the college', which would ensure coherent and efficient group supervision (ING Group, 2009: 3). Another Dutch bank, Rabobank, advocates more efficient mechanisms to resolve disagreements about regulatory issues at the European level: 'The most prudent procedure would be for the Commission, in collaboration with the industry, to continue analyzing this issue without rushing into adopting any untested approach' (Rabobank Nederland, 2010: 9). Rabobank emphasizes that regulators have sufficient tools to address any shortcomings in the banks' risk management and do not need further national discretions.

Based on the empirical evidence presented so far, we can conclude that cross-border financial companies from France, Germany, Italy and the Netherlands have indeed advocated more regulatory harmonization in European financial regulation, greater supervisory powers for home regulators, and a single European rule-book in banking. The analysed positions are consistent with findings in the literature (Posner, 2007; Hardie and Howarth, 2009). Previous research has shown that large financial firms lobbied not only their 'home' member-states, but also the European Commission (Posner, 2007). Their influence on policy outcomes has important normative repercussions. For example, Mügge (2011) has shown that the excessive influence of the financial industry has compromised the legitimacy of financial sector governance. Yet, we also observe more nuanced positions in countries that have high domestic bank internationalization, but also higher levels of foreign ownership. For example, the positions filed by Dutch public regulators are more cautious than those of private financial companies based in the Netherlands.

Hypothesis II: States where foreign ownership in banking is high and domestic bank internationalization is low prefer more national regulatory autonomy.

This part starts with an analysis of the Czech position on the powers of the ESAs, home-host supervision issues and the single rule-book in CRD IV. The Czech Republic is a typical case of the high foreign ownership group in my analysis. The Czech Central Bank maintains that extensive transfer of decision-making powers to the European level, while fiscal responsibilities remain at the national level, is unacceptable. It is particularly difficult for national supervisory bodies to align their actions with both national and 
European priorities: 'A national supervisory authority is accountable to its national Parliament... [it] cannot simultaneously be accountable to the European authorities' (Czech National Bank, 2009: 5). According to the Central Bank, European banking regulation reforms should not be more stringent than Basel III, which takes a minimum harmonization approach. At the same time, the Czech Central Bank does recognize the need for more coherence in European banking regulation and more efficient cooperation among different supervisory bodies. It supports the elimination of some national discretions, provided that the harmonized risk management rules in CRD IV are sufficiently cautious (Czech National Bank, 2010: 15).

In contrast, the position of the Czech Finance Ministry shows less flexibility and a stronger preference for national regulatory autonomy. With regard to home-host supervision, the Czech Finance Ministry (2010: 1) calls for clear cooperative rules between the home and host regulators. It wants to make sure that 'the host supervisor should be continuously informed about the level of the capital buffer held on the risk expositions located in the host country'. The ministry also argues in favour of more national discretions in setting higher countercyclical capital buffers. It explicitly links this preference to high foreign ownership in banking: 'The structure of the banking sector in the Czech Republic is mainly dominated by subsidiaries of foreign banking groups; therefore it is important for us that the capital buffers are also held at the solo level [for national regulators to conserve resources in local parts of the international financial group]' (Czech Finance Ministry, 2010: 2).

Most EU member-states from CEE voice very similar concerns. This is hardly surprising, as we know that international institutions' push for more financial sector liberalization was met with resistance in a number of CEE countries where nationalist striving and desire for autonomy were high (Vachudova, 2005; Epstein, 2008). The joint position of the main Estonian public regulators states that as long as financial stability and the resolution of failed banks are national responsibilities, 'Member States should be entitled to apply more stringent requirements to financial institutions than the common harmonised minimum requirements if necessitated by financial stability concerns' (Estonia, 2010: 13). The position explains that this national discretion contributed significantly to preserving relative stability in the Estonian banking system during the global economic turmoil. Estonian regulators put in place several anti-cyclical measures, such as a 10 per cent minimum capital requirement for all credit institutions, and an increase of the mortgage credit risk weight from 50 per cent to 100 per cent in 2006 to mitigate the rapid credit expansion. In order to maintain a level playing field, Estonian regulators asked the home supervisors of foreign banks operating via a branch structure to apply the same risk weighting to mortgage loans issued in Estonia (Estonia, 2010: 14; see also Bohle, 2013, this volume). 
Among the EU's 'older' member-states, Finland's financial sector structure is most similar to that of the new member-states. The country predominantly hosts foreign financial institutions. Thus, the Finnish position on EU regulatory reforms is an important test of the validity of Hypothesis II. While Finland (2009: 1) welcomes the progress made toward greater supervisory convergence and consistency in Europe, it also highlights the importance of 'an adequate role for the host authorities in particular visà-vis foreign branches of systemic relevance in the host country market'. In addition, the Finnish government maintains that 'supervisory responsibilities should be kept in line with deposit guarantee schemes' (2009: 5). Donnelly (2013, this volume) has shown that the absence of a common European deposit insurance regime has been an obstacle to achieving greater regulatory harmonization in general.

The Finnish position clarifies that if host supervisory authorities receive new fiscal responsibilities for the hosted branches of cross-border institutions, they should also have adequate powers to influence their risk management decisions (Finland, 2009: 5). It also warns against granting greater powers to home (or consolidated) supervisors because 'the home country authority may put less importance on supervising the foreign activities of a financial institution or group than the host authority would wish' (Finland, 2009: 4-5). Furthermore, the level playing field in the host country may be compromised if home supervisors have different levels of risk tolerance, which are then passed on to branches and subsidiaries in the host country (Finland, 2009: 5).

Poland stands out among the new member-states, with its strong domestic banking sector. So far, however, domestic-owned banks have focused predominantly on the Polish market, rather than on internationalization. The Polish position on banking supervision reforms in the EU is aligned with those of countries in the high foreign ownership and low internationalization group. Echoing the concerns of Czech regulators, for the Polish Central Bank, the ability to set more stringent standards domestically is of paramount importance. The Central Bank asserts that if national supervisors find that certain EU provisions do not provide sufficient safeguards, they 'must be able to put the financial stability of his country before the maximum harmonization of the CRD' (National Bank of Poland, 2010: 17). A compromise solution envisaged by the Polish Central Bank is to grant national supervisors the right to impose more restrictive measures if they can present a valid and convincing explanation to the EBA.

This is not to say that member-states expressing more reservations towards a large-scale harmonization of EU financial regulation deny the need to eliminate some national discretions in order to sustain a level playing field. The crux of the argument is about the optimal scope of policy coordination at the European level. The Polish Financial Supervision Authority, for example, calls for a careful assessment of which 
national options and discretions are crucial for the functioning of national supervisors and need to remain in place (Polish Financial Supervision Authority, 2009: 1). It wants to keep the power to require capital add-ons for individual financial institutions, which it sees as an important lever to control the level of risk in the national banking system (Polish Financial Supervision Authority, 2009: 2).

Overall, the evidence examined in this section confirms Hypothesis II that countries where foreign ownership is very high and domestic bank internationalization is low are more cautious about transferring extensive powers to the ESAs while substantial accountability and fiscal responsibility for bank bail-outs remain at the national level. Countries in this group such as the EU's new member-states from CEE and Finland favour a minimum harmonization approach, which safeguards more national regulatory autonomy. They also advocate greater discretionary powers for their national, also referred to as host, financial sector regulators.

\section{Idiosyncratic cases}

I now turn to discussing the positions of the idiosyncratic cases in the top left and bottom right corners of Figure 1. Slovenia, Cyprus, Malta and Portugal are characterized by low foreign ownership and low internationalization of their domestic banks. Slovenia stands out among the EU's new member-states. Relying on domestic capital, successive governments maintained state ownership of the country's biggest banks, which has given them some decision-making power over capital allocation. Slovenia's banks are mostly oriented towards boosting domestic economic growth, for example, by providing loans to small and mediumsized enterprises, the construction sector and households (Bank of Slovenia, 2010). They have also played a crucial role in supporting the expansion of small and medium-sized enterprises abroad (Svetlicic, 2007). Yet, Slovenia's banking sector has been severely affected by the global financial crisis. Bad debts have risen steadily since 2009 and non-performing loans have reached 20 per cent (International Monetary Fund, 2011). In 2012-13, the country's three largest banks urgently needed government recapitalization, and both the International Monetary Fund (IMF) and the Organisation for Economic Co-operation and Development (OECD) have advised the government to consider banking sector privatization (Fontanella-Khan, 2013).

Recent developments in Slovenia and Cyprus, especially in the aftermath of the 2013 Cyprus bank bail-out, highlight the vulnerability of these smaller banking systems. While Slovenia, Cyprus and Malta have not actively opposed initiatives for further EU regulatory harmonization in banking supervision, these countries would prefer to keep some national 
discretions. Slovenia, for example, shares the concerns of other banking supervisors in CEE and has generally advocated more discretionary powers for host supervisors (Personal interview 1, 2010).

The exception in this group is Portugal, which has been a proponent of greater EU regulatory harmonization. The main motivation for this preference seems to be political, as Portuguese governments tend to be the least Euro-sceptic in the EU and more open to EU-level regulatory harmonization (Personal interview 2, 2011). The Portuguese Ministry of Finance (2009: 3) stresses in its position that the EU should implement a single rule-book 'in order to guarantee an efficient functioning of financial markets, avoid regulatory arbitrage and facilitate crisis management in case of cross-border institutions'. It also highlights the need to include a European dimension in the mandates of national bank supervisors and build a common European supervisory culture.

Section 2 mentioned the UK, both home and host regulator of large financial institutions, as an idiosyncratic case situated in the bottom right corner of Figure 1. The UK official position is by far one of the most sceptical about granting more binding powers to the ESAs. It states that 'we do not support EU level binding powers over national supervisors, or EU level supervision of firms, given that the arrangements for resolving difficulties in these firms, including providing fiscal support, remain a national responsibility' (United Kingdom, 2009: 1). National regulators should be able to limit deposit-taking by firms based outside the EU in order to have proper safeguards against a repeat of the Icelandic banking crisis (United Kingdom, 2009: 6). The UK also stresses the importance of aligning EU regulatory reforms with internationally agreed standards such as the G-20 recommendations and the Basel accords (United Kingdom, 2009: 2). This is in line with findings in the literature. Quaglia (2008a) has shown that the UK has been a part of a 'market-making coalition' of member-states that favour EU regulatory harmonization when it expands the single market in financial services, but oppose the creation of a cumbersome European regulatory framework.

Regarding the CRD IV, in a position prepared in consultation with the Bank of England and the Financial Services Authority, the UK Treasury emphasizes the global dimension of European financial regulation. It stresses that the treatment of third country branches should also be harmonized. Otherwise, those branches would effectively evade robust European supervision. According to the UK Treasury, CRD IV should spell out clearly the obligations of host supervisors of non-European Economic Area (EEA) branches. Given the $€ 1.4$ trillion of assets held in UK branches of non-EEA groups, the UK attaches paramount importance to this issue (UK Treasury, 2010: 9).

The UK generally supports the elimination of some national discretions in CRD IV, but this is subject to two overriding principles. First, the UK 
maintains that EU level harmonization should not result in a general reduction in regulatory standards across the EU. Second, 'member states need to retain the ability to impose stricter capital requirements and/or adopt more stringent national regulatory measures considered to be domestically appropriate for safeguarding financial stability' (UK Treasury, 2010: 31). According to the Treasury's analysis, different national markets have widely different underlying mechanisms of supply and demand, which call for domestic fine-tuning of banking supervision (UK Treasury, 2010: 31-2).

The official UK government position is aligned with that of private actors with regard to the powers of the ESAs and home-host supervision. The British Bankers' Association (BBA), for example, advocates a limited role for the ESAs in binding mediation in case of disputes between national supervisors (BBA, 2009: 2). The City of London also stresses that 'we strongly support the concept of national authorities continuing to be responsible for the authorisation and supervision of individual entities' (City of London, 2009: 3). Furthermore, the BBA advocates a stronger reporting mechanism to the EU Council of Ministers, especially during crisis situations (BBA, 2009: 17).

While large UK financial institutions welcome the proposals for a single EU rule-book, they would also like to keep the system of national discretions. According to Standard Chartered (2009: 1), the single EU rule-book would boost the single market in financial services. However, the bank maintains that national discretions should remain in place to ensure that EU financial sector firms are not in a disadvantageous position when they compete with other global firms outside the EU. Standard Chartered emphasizes that granting the ESAs greater binding decision-making powers could have negative repercussions for the bank's global operations. Similarly, Barclays (2010: 8) endorses the single rule-book, but would like to make sure that 'national supervisors retain the flexibility to apply supervisory judgment in areas where it is required'.

In sum, the global repercussions of EU regulatory decisions are particularly salient for the UK. Large UK banks have stressed that any new European regulatory arrangements 'need to be consistent - and interface efficiently - with existing and new global supervisory arrangements' (BBA, 2009: 17). With regard to preserving greater national regulatory autonomy, the UK position is aligned with those of the CEE member-states and Finland. However, the motivation of large UK banks to defend national regulatory autonomy needs to be unpacked further in the light of recent reports about regulatory capture and revolving door shortcomings in UK supervisory conduct (Miller, 2009; Masters, 2012). If a private bank can rely on a cooperative attitude at the national level, it would logically prefer to be supervised primarily by the national financial regulator, rather than, presumably, a more remote European one. Buckley and Howarth's 
(2010: 126) analysis lends support to this conjecture, 'unofficially, the general consensus among UK financial groups was that their interests were fairly well served under the light-touch supervision of the FSA'.

\section{SECTION 4}

\section{ALTERNATIVE EXPLANATIONS}

Foreign ownership and domestic bank internationalization do not fully account for the observed variation in government preferences, especially concerning countries in the top left and bottom right corners of Figure 1. The level of Euro-scepticism and commitment to particular ideas about the purpose of the single market also influence countries' regulatory stances. Below, I discuss these two alternative explanations of government preferences. European political parties vary in their levels of Euro-scepticism and previous research has established that this variable has an impact on their attitudes toward European integration (Taggart and Szczerbiak, 2002; Hooghe, 2007; de Vries, 2010). We need to investigate whether Euro-sceptic parties in government are less willing to support greater European harmonization of financial regulation than their more moderate counterparts. Figure 2 reported governing parties' Euro-scepticism score, obtained from the Chapel Hill expert survey (Bakker et al., 2012). A lower score means strong opposition to European integration; the range is 1 to 7 .

The relatively high Euro-scepticism score of the UK government helps to explain the general unwillingness to transfer more regulatory powers to the European level. It provides important insights into a political explanation, complementary to the foreign ownership and domestic bank internationalization explanation put forward in this article. However, the effect of government Euro-scepticism in most European states is more volatile due to the four-year electoral cycle and subsequent government change. In contrast, bank privatization has an institutional lock-in effect that cannot be easily reversed. The bank privatization and consolidation process in Europe has not followed a uniform trend, but we could say that in Western Europe, major ownership restructuring occurred in the 1980s and 1990s, whereas in CEE, the process was completed by the early 2000s (Megginson, 2005). I have argued here that the resulting ownership structure and internationalization strategy of the financial sector play an important role in shaping countries' regulatory preferences in banking supervision.

A second alternative account refers to a government's understanding of European integration and beliefs about the purpose of the single market. This explanation goes beyond an instrumentalist cost-benefit analysis of how much countries stand to gain or lose from greater regulatory harmonization. For example, Shawn Donnelly (2013, this volume) has highlighted the norm of self-help in Economic and Monetary Union 
(EMU) governance that stipulates the proper role of the state in managing economic policy. This norm has been a powerful driver of state behaviour during the European sovereign debt crisis. States that have internalized it deeply, such as Germany, assert that national financial stability is paramount, regardless of functional incentives for greater harmonization at the EU level (Donnelly, 2013, this volume). Similar dynamics may take place in financial regulation. Internalization of the self-help norm may explain why some states attach great importance to national regulatory autonomy and why some national financial regulators maintain that their core mission is to safeguard national financial stability.

Huw Macartney's (2013, this volume) analysis of the UK government's beliefs about the role of the state in finance sheds more light on the UK's preferences in EU financial regulation. Macartney demonstrates that despite being widely known as a proponent of market liberalization and greater competition, the UK has kept significant segments of its banking system underexposed to foreign competition. He explains this outcome by citing the deep-held belief of UK policymakers that domestically-owned financial institutions would support the domestic economy in times of crisis. Yet, as Macartney has shown, the state's beliefs about the proper actions of domestically-owned financial institutions did not match the actual behaviour of 'home' financial institutions. The UK government failed to induce greater bank lending to small and medium-sized enterprises in the wake of the global financial crisis. To sum up, ideational accounts show better the cognitive underpinnings of government preferences. The main evidence that I have considered came from states' and private actors' revealed preferences about European financial regulation. Ideational accounts probe deeper the beliefs informing revealed preferences, and I view them as complementary to the analysis carried out in this article.

\section{SECTION 5 \\ CONCLUSION}

This article examined three areas of European banking supervision in which substantial progress has been made since 2008 towards more harmonization at the EU level. Yet, policy coordination has resulted from protracted negotiations, which revealed considerable differences in the regulatory preferences of the EU's member-states. I have argued that the levels of foreign ownership and domestic bank internationalization are important determinants of regulatory preferences. The first policy issue examined here referred to granting more binding regulatory powers to the supranational European Supervisory Authorities (ESAs). The second issue was distributing supervisory power and competences between the home and host supervisory organizations of cross-border financial institutions. 
The third issue concerned introducing a single rule-book in banking and discontinuing national discretions in the Capital Requirements Directive (CRD) IV, which implements Basel III in the EU.

I found sufficient empirical evidence in support of Hypothesis I that countries with low levels of foreign ownership and high internationalization of domestic banks, such as France, Germany, Italy and the Netherlands, are in favour of further banking supervision harmonization at the EU level. In line with Hypothesis II, countries where foreign ownership is very high and domestic bank internationalization is low, such as the EU's new member-states from CEE and Finland, favour more autonomy for their national (host) financial sector regulators.

This is not to say that governments with more reservations about extensive transfer of regulatory competences to the European level oppose further financial sector integration in the EU. Decision-makers understand the benefits of coherent European regulations in finance and a level playing field, which explains the substantial progress towards more harmonization since 2008. The issue on which European governments disagree is: what is the optimal scope of regulatory harmonization? The dilemma in European regulatory harmonization is similar to the one faced by countries entering the Eurozone. A common monetary policy cannot be tailored to the specific circumstances of each member-state. Similarly, a common banking supervision regime cannot be tailored to the risk-tolerance profile and concerns of each member-state. I have shown that being a host jurisdiction to foreign banks constrains states' ability to steer credit flows and tackle perceived threats to national financial stability. This, in turn, raises decision-makers' sensitivity toward a full-scale transfer of regulatory authority away from the national level.

As the European banking union is taking shape, there is momentum for further harmonization of banking supervision. The single supervisory mechanism (SSM) has put the European Central Bank (ECB) at the forefront of supervising the largest Eurozone banks. Yet, the tension between regulatory harmonization and national regulatory autonomy persists. In particular, scholars are warning about a possible emergence of voting alliances of Eurozone versus non-Eurozone member-states in the EBA, which develops technical standards for the entire EU and closely coordinates banking supervision policy with the ECB (Ferran and Babis, 2013). The European sovereign debt crisis has also highlighted that smaller states, whose domestic financial sectors are vulnerable to capital flight, seek to preserve more national regulatory autonomy. This would allow them to intervene quickly and decisively, bypassing the new and more time-consuming mechanisms for multilateral policy coordination at the EU level. The paradox of such national safeguard mechanisms is that they undermine the newly established policy coordination channels and may produce suboptimal outcomes for all member-states in the long run. 


\section{ACKNOWLEDGMENTS}

I would like to thank Rachel Epstein for her invaluable feedback and the participants of the Economic Nationalism versus Financial Integration workshop held at the University of Denver for their constructive comments on previous drafts of this article. I am grateful to Ilene Grabel and two anonymous RIPE reviewers for their detailed comments, which helped me clarify and hone my argument.

\section{REFERENCES}

Alford, D. (2010) 'Supervisory Colleges: The Global Financial Crisis and Improving International Supervisory Coordination', Emory International Law Review, 24: 57-82.

Armstrong, K. and S. Bulmer, S. (1998) The Governance of the Single European Market, Manchester: Manchester University Press.

Association of German Banks (BV) (2009) 'Comments of the on the Communication from the European Commission on European Financial Supervision', 15 July. Available from: https://circabc.europa.eu/faces/ jsp/extension/wai/navigation/container.jsp.

Bache, I. and Flinders, M. (eds) (2004) Multi-level Governance, Oxford: Oxford University Press.

Bakker, R., de Vries, C., Edwards, E., Hooghe, L., Jolly, S., Marks, G., Polk, J., Rovny, J., Steenbergen, M. and Vachudova, M. (2012) 'Measuring Party Positions in Europe: The Chapel Hill Expert Survey Trend File, 1999-2010', Forthcoming in Party Politics. doi:10.1177/1354068812462931.

Bank of Italy (2010) 'Bank of Italy Response to the EU Commission Consultation Regarding Further Possible Changes to the Capital Requirements Directive (CRD)', April 2010. Available from: https://circabc.europa.eu/ faces/jsp/extension/wai/navigation/container.jsp.

Bank of Slovenia (2010) Financial Stability Review, Ljubljana: Bank of Slovenia.

Barclays Bank PLC (2010) 'Barclays Response to Possible Further Changes to the Capital Requirements Directive Consultation.' Available from: https:/ / circabc. europa.eu/faces/jsp/extension/wai/navigation/container.jsp.

Barker, A. (2012) 'EU Ministers at Odds over Banking Union', The Financial Times, 15 September.

Barker, A., Peel, Q. and Wiesmann, G. (2013) 'Battle Looms over Failed Lenders', The Financial Times, 13 December.

BNP Paribas (2009) 'BNP Paribas Response to the European Commission's Consultation on European Financial Supervision.' Available from: https:// circabc.europa.eu/faces/jsp/extension/wai/navigation/container.jsp.

Bohle, D. (2013) 'Post-socialist Housing Meets Transnational Finance: Foreign Banks, Mortgage Lending, and the Privatization of Welfare in Hungary and Estonia', Review of International Political Economy, DOI: 10. 1080/09692290.2013.801022.

British Bankers' Association (BBA) (2009) 'Commission Consultation on Financial Market Supervision', 9 April. Available from: https://circabc.europa.eu/ faces/jsp/extension/wai/navigation/container.jsp.

Buckley, J. and Howarth, D. (2010) 'Internal Market: Gesture Politics? Explaining the EU's Response to the Financial Crisis', Journal of Common Market Studies, 48(Annual Review): 119-41. 
Buckley, J. and Howarth, D. (2011) 'Internal Market: Regulating the So-called “Vultures of Capitalism"', Journal of Common Market Studies, 48(Annual Review): 123-43.

Buckley, J., Howarth, D. and Quaglia, L. (2012) 'Internal Market: The Ongoing Struggle to "Protect" Europe from Its Money Men', Journal of Common Market Studies, Volume 50(Annual Review): 99-115.

Buiter, W. and Rahbari, E. (2012) 'The European Central Bank as Lender of Last Resort for Sovereigns in the Eurozone', Journal of Common Market Studies, Volume 50(Annual Review): 6-35.

Centre for Economic Policy Research (CEPR) (2011) Cross-border Banking in Europe: Implications for Financial Stability and Macroeconomic Policies, London: Centre for Economic Policy Research.

City of London (2009) 'European Commission Communication on European Financial Supervision. Response from the City of London', 15 July. Available from: https://circabc.europa.eu/faces/jsp/extension/wai/navigation/container. jsp.

Claessens, S., Herring, R., Schoenmaker, D. and Summe, K. (2010) A Safer World Financial System: Improving the Resolution of Systemic Institutions, Geneva Reports on the World Economy 12, London: Centre for Economic Policy Research.

Confederation of the Nordic Bank, Finance and Insurance Unions (NFU) (2009) 'NFU Response to Consultation on Commission Communication on European Financial Supervision', 10 July. Available from: https://circabc. europa.eu/faces/jsp/extension/wai/navigation/container.jsp.

Crédit Agricole (2009) 'Crédit Agricole S.A. Response to the European Commission Consultation on European Financial Supervision', 15 July. Available from: https://circabc.europa.eu/faces/jsp/extension/wai/navigation/container. jsp.

Czech Finance Ministry (2010) 'Ministry of Finance of the Czech Republic. Response to Consultation Document on Countercyclical Capital Buffers', November. Available from: https://circabc.europa.eu/faces/jsp/extension/ wai/navigation/container.jsp.

Czech National Bank (2009) 'Position of the Czech National Bank on the Communication from the Commission - European Financial Supervision'. Available from: https://circabc.europa.eu/faces/jsp/extension/wai/ navigation/container.jsp.

Czech National Bank (2010) 'The Czech National Bank's Opinion on the Consultation Document of the European Commission "Possible Further Changes to the Capital Requirements Directive", April. Available from: https://circabc. europa.eu/faces/jsp/extension/wai/navigation/container.jsp.

Dinan, D. (2012) 'Governance and Institutions: Impact of the Escalating Crisis', Journal of Common Market Studies, 50(Annual Review): 85-98.

Deutsche Bank Research (2008) European Banks: The Silent (R)evolution, Frankfurt am Main: Deutsche Bank Research.

de Vries, C. (2010) 'EU Issue Voting; Asset or Liability: How European Integration Affects Parties' Electoral Fortunes', European Union Politics, 11(1): 89-117.

Donnelly, S. (2010) The Regimes of European Integration: Constructing Governance of the Single Market, Oxford: Oxford University Press.

Donnelly, S. (2013) 'Power Politics and the Undersupply of Financial Stability in Europe', Review of International Political Economy, DOI: 10. 1080/09692290.2013.801021.

Epstein, R.A. (2008) 'The Social Context of Conditionality: Internationalizing Finance in Postcommunist Europe', Journal of European Public Policy, 15(6): 880-98. 
Epstein, R.A. (2013a) 'Introduction to the Special Issue', Review of International Political Economy.

Epstein, R.A. (2013b) 'When Do Foreign Banks "Cut and Run"? Evidence from West European Bail-Outs and East European Markets', Review of International Political Economy.

Estonia (2010) 'Response to Consultation Regarding Further Possible Changes to the Capital Requirements Directive (CRD) by the Ministry of Finance of Estonia, Bank of Estonia and the Estonian Financial Supervision Authority'. Available from: https://circabc.europa.eu/faces/jsp/extension/ wai/navigation/container.jsp.

EurActive (2010) 'MEPs Want Large Banks under EU Thumb', 10 February.

European Banking Federation (2009) 'EBF Response to Commission Consultation on the Improvement of Supervision for the Financial Services Sector', 9 April. Available from: https://circabc.europa.eu/faces/jsp/extension/ wai/navigation/container.jsp.

European Central Bank (ECB) (2007) Review of the Lamfalussy Framework. Eurosystem Contribution, Frankfurt: ECB. Available at: http://www.ecb. europa.eu/pub/pdf/other/lamfalussy-review2007en.pdf.

European Commission (2005) 'White Paper. Financial Services Policy 2005-2010'. Available at: http://ec.europa.eu/internal_market/finances/docs/white_ paper/white_paper_en.pdf.

European Commission (2009b) 'European Financial Integration Report 2008', SEC(2009) 19 final. Available at: http://ec.europa.eu/internal_market/ finances/docs/cross-sector/fin-integration/efir_report_2008_en.pdf.

European Commission (2009c) 'Proposal for a Directive in Respect of the Powers of the European Banking Authority, the European Insurance and Occupational Pensions Authority and the European Securities and Markets Authority', COM(2009) 576 final. Available at: http://ec.europa.eu/internal_ market/finances/docs/committees/supervision/20091026_576_en.pdf.

European Commission (2011a) 'Proposal for a Directive of the European Parliament and the Council on the Access to the Activity of Credit Institutions and the Prudential Supervision of Credit Institutions and Investment Firms and Amending Directive 2002/87/EC of the European Parliament and of the Council on the Supplementary Supervision of Credit Institutions, Insurance Undertakings and Investment Firms in a Financial Conglomerate', COM(2011) 453 final, 20 July. Available at: http://eur-lex. europa.eu/LexUriServ/LexUriServ.do?uri=COM:2011:0453:FIN:en:PDF.

European Commission (2011b) 'Commission Staff Working Paper Impact Assessment', SEC(2011) 952 final, 20 July.

Ferran, E. and Babis, V. (2013) 'The European Single Supervisory Mechanism', University of Cambridge Legal Studies Research Paper Series, Paper No. 10/2013, http:/ / ssrn.com/abstract=2224538 (accessed 12 April 2011).

Finland (2009) 'Comments Regarding the Development of Financial Supervision at the EU Level', Available from: https://circabc.europa.eu/ faces/jsp/extension/wai/navigation/container.jsp.

Fontanella-Khan, J. (2013) 'Slovenia Dismisses Cyprus Comparisons', The Financial Times, 2 April.

France (2010) 'European Commission's Consultation Paper on CRD IV. Reply of the Ministry of the Economy, Bank of France, and General Secretariat of the Bank Supervision Authority', April. Available from: https://circabc. europa.eu/faces/jsp/extension/wai/navigation/container.jsp.

French Financial Markets Authority (AMF) (2009) 'Contribution by the AMF on the Improvement of Financial Supervision in the European Union', 
15 April. Available from: https://circabc.europa.eu/faces/jsp/extension/ wai/navigation/container.jsp.

Frieden, J. (2002) 'Real Sources of European Currency Policy: Sectoral Interests and European Monetary Integration', International Organization, 56(4): 831-860.

Garrett, G. (1992) 'International Cooperation and Institutional Choice: The European Community's Internal Market', International Organization, 46(2): 41-76.

Groenleer, M. (2011) 'Regulatory Governance in the European Union: The Political Struggle over Committees, Agencies and Networks', in D. LeviFaur (ed.) Handbook on the Politics of Regulation, Cheltenham: Edward Elgar, pp. 548-562.

Grossman, E. and Leblond, P. (2011) 'European Financial Integration: Finally the Great Leap Forward?', Journal of Common Market Studies, 49(2): 413-35.

Hardie, I. and Howarth, D. (2009) 'Die Krise but not La Crise? The Financial Crisis and the Transformation of German and French Banking Systems', Journal of Common Market Studies, 47(5): 1017-39.

Hodson, D. (2012) 'The Eurozone in 2011', Journal of Common Market Studies, 50(Annual Review): 178-94.

Hooghe, L. (2007) 'What Drives Euroskepticism? Party-Public Cueing, Ideology and Strategic Opportunity', European Union Politics, 8(1): 5-12.

Hooghe, L. and Marks, G. (2003) 'Unraveling the Central State, but How? Types of Multi-level Governance', American Political Science Review, 97(2): 233-43.

Hosli, M.O. (2000) 'The Creation of the European Economic and Monetary Union (EMU): Intergovernmental Negotiations and Two-level Games', Journal of European Public Policy, 7(5): 744-66.

Howarth, D. and Sadeh, T. (2010) 'The Ever Incomplete Single Market: Differentiation and the Evolving Frontier of Integration', Journal of European Public Policy, 17(7): 922-35.

Howarth, D. and Quaglia, L. (2012) 'The Domestic Political Economy of Basel III and CRD IV', Presentation at the College of Europe Workshop, 'Redefining European Economic Governance', 1 March.

ING Group (2009) 'ING Response to European Commission Consultation on Financial Supervision in Europe', 17 July. Available from: https://circabc. europa.eu/faces/jsp/extension/wai/navigation/container.jsp.

International Monetary Fund (IMF) (2011) 'Republic of Slovenia: 2011 Article IV Consultation - Staff Report; Public Information Notice on the Executive Board Discussion; Staff Statement; and Statement by the Executive Director for Slovenia', IMF Country Report No. 11/121. Available at: http://www.imf. org/external/pubs/ft/scr/2011/cr11121.pdf.

Jenkins, P. (2012) 'Banking Union Must Halt Balkanisation', The Financial Times, 10 September.

Kudrna, Z. (2012) 'Cross-border Resolution of Failed Banks in the European Union after the Crisis: Business as Usual', Journal of Common Market Studies, 50(2): 283-99.

Kudrna, Z. and Gabor, D. (2013) 'The Return of Political Risk: Foreign-owned Banks in Emerging Europe', Europe-Asia Studies, 65(3): 548-566.

Lütz, S. (2011) 'Back to the Future? The Domestic Sources of Transatlantic Regulation', Review of International Political Economy, 18(4): iii-xxii.

Macartney, H. (2013) 'From Merlin to Oz: The Strange Case of Failed Lending Targets in the UK', Review of International Political Economy.

Masters, B. (2012) 'Enter the Revolving Regulators', The Financial Times, 23 April.

Megginson, W.L. (2005) 'The Economics of Bank Privatization', Journal of Banking and Finance, 29: 1931-80. 
Miller, D. (2009) 'Revolving Doors, Accountability and Transparency: Emerging Regulatory Concerns and Policy Solutions in the Financial Crisis', Presentation at the OECD, Paris, 6 July.

Moschella, M. (2010) 'Back to the Drawing Board: The International Financial Architecture Exercise', Review of International Political Economy, 17(1): 155-71.

Mügge, D. (2010) Widen the Market, Narrow the Competition: Banker Interests and the Making of a European Capital Market, Colchester: ECPR Press.

Mügge, D. (2011) 'Limits of Legitimacy and the Primacy of Politics in Financial Governance', Review of International Political Economy, 18(1): 52-74.

National Bank of Poland (2010) 'Position of the National Bank of Poland on the Commission Services Staff Working Document: Possible Further Changes to Capital Requirements Directive', April. Available from: https:// circabc.europa.eu/faces/jsp/extension/wai/navigation/container.jsp.

Oatley, T. and Nabors, R. (1998) 'Redistributive Cooperation: Market Failure, Wealth Transfers, and the Basle Accord', International Organization, 52(1): 35-54.

Personal interview 1 (2010) Anonymous official from the Permanent Representation of Slovenia to the European Union, December, Brussels.

Personal interview 2 (2011) Anonymous official from the Bank of Portugal, interviewed at the OECD, 4 October, Paris.

Piattoni, S. (2010) The Theory of Multi-level Governance: Conceptual, Empirical, and Normative Challenges, Oxford: Oxford University Press.

Polish Financial Supervision Authority (2009) 'KNF Response to European Commission Consultation on the Future of Financial Services Supervision in the $\mathrm{EU}^{\prime}$. Available from: https://circabc.europa.eu/faces/jsp/ extension/wai/navigation/container.jsp.

Porter, T. (2003) 'Technical Collaboration and Political Conflict in the Emerging Regime for International Financial Regulation', Review of International Political Economy, 10(3): 520-51.

Portuguese Ministry of Finance (2009) 'Response to the European Commission Consultation on the Improvement of Supervision for the Financial Services Sector', 10 April. Available from: https://circabc.europa.eu/faces/ jsp/extension/wai/navigation/container.jsp.

Posner, E. (2007) 'Financial Transformation in the European Union', in Kathleen McNamara and Sophie Meunier (eds) Making History: European Integration and Institutional Change at Fifty (State of the European Union, Vol. 8), Oxford: Oxford University Press, pp. 139-156.

Posner, E. (2010) 'The Lamfalussy Process: Polyarchic Origins of Networked Financial Rule-making in the EU', in C. Sabel and J. Zeitlin (eds) Experimentalist Governance in the European Union. Towards a New Architecture, Oxford: Oxford University Press, pp. 43-60.

Posner, E. and Véron, N. (2010) 'The EU and Financial Regulation: Power without Purpose', Journal of European Public Policy, 17(3): 400-15.

Quaglia, L. (2007) 'The Politics of Financial Services Regulation and Supervision Reform in the European Union', European Journal of Political Research, 46(2): 269-290.

Quaglia, L. (2008a) 'Financial Sector Committee Governance in the European Union', Journal of European Integration, 30(4): 563-78.

Quaglia, L. (2008b) 'Setting the Pace? Private Financial Interests and European Financial Market Integration', British Journal of Politics and International Relations, 10(1): 46-63.

Quaglia, L. (2010) Governing Financial Services in the European Union: Banking, Securities and Post-Trading, London: Routledge. 
Rabobank Nederland (2010) 'Response to CRD IV consultation', April. Available from: https://circabc.europa.eu/faces/jsp/extension/wai/navigation/ container.jsp.

Rosenbluth, F.M. and Schaap, R. (2003) 'The Domestic Politics of Banking Regulation', International Organization, 57(2): 307-36.

Singer, D.A. (2004) 'Capital Rules: The Domestic Politics of International Regulatory Harmonization', International Organization, 58(3): 531-65.

Singer, D.A. (2007) Regulating Capital: Setting Standards for the International Financial System, Ithaca, NY: Cornell University Press.

Slager, A. (2005) 'Internationalization of Banks: Strategic Patterns and Performance', SUERF - The European Money and Finance Forum, SUERF Studies 2005/4.

Spendzharova, A. (2012) 'Is More "Brussels" the Solution? New European Union Member States' Preferences about the European Financial Architecture', Journal of Common Market Studies, 50(2): 315-34.

Standard Chartered (2009) 'Reply to Commission Consultation on Supervisory Reforms', 15 July. Available from: https://circabc.europa.eu/faces/ jsp/extension/wai/navigation/container.jsp.

Svetlicic, M. (2007) 'Outward Foreign Direct Investment by Enterprises from Slovenia', Transnational Corporations, 16(1): 55-88.

Taggart, P. and Szczerbiak, A. (2002) 'The Party Politics of Euroscepticism in EU Member and Candidate States', Sussex European Institute Working Paper No. 51.

Tait, N. (2010) 'MEPs Want More Financial Watchdog Powers', The Financial Times, 10 February.

The Financial Times (2009) 'Single Market Rules', 24 September,.

The Netherlands (2009) 'Response by the Netherlands to the European Commission's Communication on European Financial Supervision'. Available from: https://circabc.europa.eu/faces/jsp/extension/wai/navigation/container. jsp.

UK Treasury (2010) 'UK Response to the Commission Services Staff Working Document on Further Possible Changes to the Capital Requirements Directive', 1 April. Available from: https://circabc.europa.eu/faces/ jsp/extension/wai/navigation/container.jsp.

UniCredit (2009a) 'Cross-border Banking in Europe: What Regulation and Supervision?', Discussion Paper N1, March. Available from: https:/ / circabc.europa. $\mathrm{eu} / \mathrm{faces} / \mathrm{jsp} / \mathrm{extension/wai/navigation/container.jsp.}$

UniCredit (2009b) 'Reply to the EU Commission Consultation on Financial Supervision on Behalf of UniCredit', 15 July. Available from: https: / circabc.europa. $\mathrm{eu} / \mathrm{faces} / \mathrm{jsp} /$ extension/wai/navigation/container.jsp.

UniCredit (2010) 'UniCredit Group's Reply to the European Commission Consultation on the Capital Requirements Directive', April. Available from: https://circabc.europa.eu/faces/jsp/extension/wai/navigation/container. jsp.

United Kingdom (2009) 'UK Government and FSA Response to the European Commission Consultation on the Future of Financial Services Supervision in the $\mathrm{EU}^{\prime}$. Available from: https://circabc.europa.eu/faces/ jsp/extension/wai/navigation/container.jsp.

Vachudova, M.A. (2005) Europe Undivided: Democracy, Leverage and Integration after Communism, Oxford: Oxford University Press. 